CHOOSE TO FIGHT OR CHOOSE TO FLEE? A NETWORK EMBEDDEDNESS

PERSPECTIVE OF EXECUTIVE SHIP JUMPING IN DECLINING FIRMS

\begin{abstract}
RESEARCH SUMMARY

Executives in declining firms may engage in ship-jumping behavior or (i.e., voluntarily move to new employers before the failure occurs) to avoid the stigma of failure. However, it is unclear how executives decide whether or not to jump ship. Building on a network embeddedness perspective, we highlight how three network-based indicators (i.e., executive social capital, the social capital of other peers in the declining firm, and the declining firm's alliance network) influence the executive-level ship-jumping decision by shaping its benefits and opportunity costs. Using data from executives at failing firms in China, we find support for our hypothesized relationships. Our research provides important insight into the network mechanisms driving the ship-jumping decision.
\end{abstract}

\title{
MANAGERIAL SUMMARY
}

Executives at failing firms have a choice: stay and attempt to rescue the firm from failure or exit and avoid the stigma of the failure (i.e., jump ship). Yet little is known about what factors affect this choice. We propose that social capital will play an important role in the decision. Our evidence from specially treated $\left({ }^{*} \mathrm{ST}\right)$ public firms in China finds that ship jumping is lowest at low and high values of social capital and highest at moderate levels of social capital (an inverted U-shaped relationship). In addition, higher levels of peer social capital (in the declining firm) as well as a well-established firm-level alliance network discourage the ship-jumping choice.

Keywords: jumping ship, executive social capital, peer social capital, alliance networks, declining firms 


\section{INTRODUCTION}

When a firm confronts a severe decline, its executives can be motivated to “jump ship,” defined as voluntary exit from the declining firm and accepting employment elsewhere (Marcel and Cowen, 2014; Semadeni et al., 2008). As the major agents of their firms, executives are often perceived as personally associated with and responsible for their firms' negative outcomes, including organizational failure (Carpenter, Geletkanycz, and Sanders, 2004; Meindl and Ehrlich, 1987). Since the elevated failure risk of a declining firm threatens its executives with stigmatization (Pozner, 2008), a central benefit of ship-jumping behavior is to protect the executives from personal stigmatization should the firm fail (Semadeni et al., 2008).

However, an executive jumping ship from a declining firm may also incur significant opportunity costs. For example, despite its poor performance, a declining firm may still possess valuable resources (Singh, 1993). By exiting from this firm, executives sacrifice access to those important and possibly irreplaceable resources (Perry, 1984; Semadeni et al., 2008), especially if the firm emerges from the decline. These benefits and opportunity costs of ship jumping together present a dilemma for executives in declining firms, leaving open the following question: How do executives decide whether (or not) to jump ship from a declining firm?

We resolve this dilemma drawing on a network embeddedness perspective (Carpenter, Li, and Jiang, 2012). Network embeddedness refers to the fact that actors are subject to the influences of social ties and networks they participate in (Granovetter, 1985:482). These networks, which provide both valuable resources and support to participants and exert significant constraints on their actions, largely shape the participants' decisions by altering the potential benefits and costs of their options (Burt, 1992; Lin, 2001). Particularly, it has been widely noted that executives are embedded in multiple networks with important stakeholders within and 
beyond their firms (e.g., interlocked boards, peers in their firms, personal contacts, interfirm exchanges, etc., see Carpenter et al., 2012; Rogan, 2014). Drawing on this insight, we posit that for executives in declining firms, embeddedness in these networks affects the ship-jumping decision by shaping the potential costs and benefits of doing so.

Following the above logic, we highlight the implications of three key networks of executives for their ship-jumping decision. The first network is executive social capital defined as the web of an executive's personal ties with external stakeholders. ${ }^{1}$ High levels of social capital provide more access to external employment opportunities and thus facilitate shipjumping behavior (Burt, 1992; Seibert, Kraimer, and Liden, 2001). However, high levels of social capital can also reduce the motivation to jump ship by protecting executives from stigma generated by the crises in their firms (Wiesenfeld, Wurthmann, and Hambrick, 2008; Zajonc, 1980). High levels of social capital also enhance the executives' ability to help their firms emerge from the decline (Hayward, Shepard, and Griffin, 2006), and increase the potential costs of ship jumping due to network embeddedness effects (Carpenter et al., 2012; Fevre, 2000). The reverse holds for low levels of executive social capital. We thus predict an inverted U-shaped relationship between executive social capital and ship-jumping behavior, such that executives with moderate levels of social capital are the most likely to jump ship from declining firms.

Moreover, executives are embedded in the networks of interfirm relationships established through their firms' operation, what we define as firm-specific networks (Carpenter et al., 2012). By working closely with other peers in their firms, executives are enmeshed in the personal contacts of these peers. Similarly, executives represent their firms in interfirm networks and thus

\footnotetext{
${ }^{1}$ Here we define executive social capital as connections with outside stakeholders beyond their firms, i.e., their outward networks (Carpenter et al., 2012). Although executives' connections with others in their firms can also be important components of their social networks, these inward connections tend to affect their decisions in distinctive ways (e.g., Jiang et al., 2014). For that reason, we limit executive social capital to outward networks, and capture the effects of inward connections separately (i.e., peer social capital).
} 
are connected with their firms’ interfirm contacts (Gulati and Westphal, 1999; Zajac, 1988). We capture the effects of these two firm-specific networks using two constructs - peer social capital, which refers to the social capital of other executives and directors in the declining firm, and the firm's alliance network, which refers to the web of collaborative relationships between the declining firm and its interfirm partners. We posit that the two firm-specific networks will discourage ship-jumping behavior. First, due to the focal executives' embeddedness in the two firm-specific networks, peer social capital and firm alliance networks both benefit and constrain the focal executives, thus increasing the opportunity costs of jumping ship. Moreover, both peer social capital and alliance networks can help declining firms emerge from the crisis (Daily and Dalton, 1995), thus reducing the potential benefit of and perceived need to jump ship.

Our research seeks to make two major contributions. First, poor firm performance is among the most prevalent antecedents of executive exit (Kang and Shivdasani, 1995; Shen and Cannella, 2002). However, with few exceptions (e.g., Semadeni et al., 2008), prior studies have predominately emphasized involuntary executive turnover. In contrast, little is known about voluntary exit, especially how executives decide whether to stay or leave. As such, we advance the strategic leadership literature by highlighting the mechanisms behind ship-jumping behavior.

Second, prior network studies have typically viewed executives’ social capital as a firmlevel resource that is used for the benefit of the firm (Acquaah, 2007; Peng and Luo, 2000). We show that this approach may be incomplete. That is, our findings suggest that executives can also use social capital to serve their personal interests, helping them to jump ship, thereby abandoning a firm in crisis. As such, we contribute to social capital research by providing a more complete explanation of the implications of executive social capital and highlighting an important boundary condition of its firm-level benefits. 


\section{THEORETICAL BACKGROUND}

\section{Executives in declining firms: A cost-benefit dilemma}

As part of their employment, executives secure important rewards from their firms (Hambrick, Geletkanycz, and Fredrickson, 1993; Zajac, 1988). Firms provide their executives with economic rewards in exchange for effort and resources (e.g., social connections, expertise, information, legitimacy), which reduce uncertainty and stabilize operations (Belliveau, O'Reilly, and Wade, 1996; Carpenter, Sanders, and Gregersen, 2001). Moreover, executives can leverage the resources of their firms to develop their personal reputations and identities (Hambrick et al., 1993; Zajac, 1988). For example, work experience in high-status firms enhances an executive’s value in the labor market (Finkelstein, Hambrick, and Cannella, 2009; Wiersema, 2002). As such, jumping ship involves opportunity costs, such as loss of access to the firm's resources, diminished personal resources (e.g., the loss of firm-specific knowledge) and potential disturbance of the ship jumper’s social identity (Castanias and Helfat, 1991; Lipsey and Steiner, 1975; Perry, 1984). These opportunity costs of ship jumping help bond executives to their firms.

However, the opportunity costs of ship jumping are complicated if the firm is in decline. Specifically, compared with healthy firms, a distinct feature of declining firms is their high risk of failure. The failure of a firm is widely recognized as a strongly discrediting event and an important source of stigma (Boeker, 1992; Semadeni et al., 2008). Stigma refers to the damage to an actor's identity deriving from proximity to socially discrediting events, characteristics, or associations (Devers et al., 2009; Goffman, 1963). In other words, a firm’s discrediting events may extend to its executives, damaging their personal identities (Pozner, 2008). For this reason, staying in a declining firm may lead to personal losses for executives should the firm fail, such as damaged reputations and devaluation in the labor market (Boivie, Graffin, and Pollock, 2012). 
Accordingly, proactively jumping ship from their current declining firm can benefit the executives, protecting them from being personally stigmatized by the possible failure of the firm (Semadeni et al., 2008).

To summarize, as their firms experience significant declines, executives may both benefit from jumping ship and face significant opportunity costs in doing so. On the one hand, the risk of personal stigmatization by staying in the declining firm likely motivates the executive to exit. On the other hand, despite its falling performance, declining firms often possess valuable resources, some of which may help reverse the decline (Singh, 1993). By jumping ship from a declining firm, the executive may incur significant opportunity costs from loss of access to those resources. The coexistence of these important benefits and opportunity costs thus presents a dilemma for the ship-jumping decisions of executives in declining firms.

\section{Resolving the dilemma of ship jumping: A network embeddedness perspective}

We draw on the network embeddedness perspective (Granovetter, 1985; Uzzi, 1997) to address the above dilemma. This perspective argues that actors' decisions are strongly affected by the social ties and networks they participate in. Particularly, social networks can shape actors' decisions by affecting the potential benefits and costs of a particular choice (Carpenter $e t$ al., 2012). On the one hand, actors may rely on relational partners in their networks for valuable support and resources (Pfeffer and Salancik, 1978). Their decisions and actions may potentially amplify or undermine these relational rents in their social networks, thus leading to certain benefits or opportunity costs. For example, prior studies have shown that among alliance partners, those with lower status enjoy more network benefits than their higher-status partners, thus encouraging peripheral firms to more actively seek cooperation with central firms (e.g., Ahuja, Polidoro, and Mitchell, 2009; Lin, Yang, and Arya, 2009). 
On the other hand, social networks may also exert instrumental constraints on participants through social norms and structural path dependence (Gulati and Gargiulo, 1999; Snijders, van de Bunt, and Steglich, 2010; Watts, 1999), potentially encouraging or discouraging certain options (Blau, 1964; Granovetter, 1985). For instance, Fei (1992) showed that actors with more cohesive personal networks tend to have higher levels of socioemotional stress and more harm to their reputations when they are involved in misconduct, thus motivating them to avoid such behaviors.

Commensurate with this perspective, we expect that for executives in declining firms, their social networks play critical roles in determining both the benefits and opportunity costs of ship jumping, and thus shape the ultimate selection (stay or leave). Particularly, simultaneously serving as strategic leaders in their firms and as individuals in their own personal lives (Carmeli, 2003; Nelson and Burke, 2000), executives are embedded in the networks of social ties with stakeholders within and beyond their firms. On the one hand, the executives are surrounded by the personal networks with external stakeholders (i.e., their executive social capital). On the other hand, the executives serve as representatives in the particular positions their firms possess in overall interfirm networks, and therefore are embedded in the firm-specific networks developed through the operations of their firms (Carpenter et al., 2012; Gulati and Westphal, 1999), such as the personal networks of other executives and directors and the firms’ alliance networks. These networks all provide benefits to and exert constraints on the focal executives, thus potentially determining their ship-jumping decision.

Building on the theory outlined above, we develop hypotheses to investigate the embeddedness influences of executive social capital and the two firm-specific networks (peer social capital, and firm alliances) on executives’ ship-jumping decisions in declining firms. 


\section{HYPOTHESIS DEVELOPMENT}

\section{Executive social capital and ship jumping}

It has been widely noted that executives’ social capital plays important roles in turnover decisions (Finkelstein et al., 2009). On the one hand, executives’ social contacts with external stakeholders are a key source of information on potential job opennings that may stimulate shipjumping behavior (Burt, 1992; Dess and Shaw, 2001; Seibert et al., 2001). On the other hand, executives’ social capital, which is a highly valuable strategic asset to their employers (Acquaah, 2007; Peng and Luo, 2000), determines their attractiveness to potential employers and thus shapes the accessibility of external job opprtunities. For these reasons, as executives' social capital increases, they are aware of more alternative employment opportunities and more capable of securing these opportunities, thus facilitating the ship-jumping choice. In contrast, as their social capital declines, executives have lower awareness of available job openings and less access to the job openings of which they are aware, and, as a result, endure longer job searches and a diminished ability to jump ship from declining firms.

Despite the benefits of social capital discussed above, executives with high levels of social capital may not want to exit from a declining firm. Specifically, high levels of social capital can provide several buffering mechanisms that protect executives from being stigmatized by the crises and prospective failure of their firms (Jiang et al., 2014; Wiesenfeld et al., 2008). First, as social capital increases, executives are broadly perceived by observers as more reliable, credible, and competent (D'Aveni, 1990; Giordano, 1983). These positive stereotypes can alter the ways that external stakeholders interpret and attribute the failure or crisis of a firm, such that observers are more likely to excuse executives with high levels of social capital, sometimes even when they are highly culpable (Hollander, 1958; Sonenshein, 2007; Weick, 1995). In contrast, 
executives with lower levels of social capital may not be afforded the same social justifications, and thus are more likely to be blamed by external stakeholders for their firms’ shortcomings.

Second, as social capital increases, interpersonal codes of mutual support and trustworthiness embedded in social networks motivate the executives’ personal contacts to support them and tolerate their mistakes (Jiang et al., 2014). In contrast, executives with lower levels of social capital will receive lower levels of support and tolerance of mistakes from their personal contacts, thus forcing them to bear more stigma should the firm fail.

Third, as social capital increases, executives can use their interpersonal social networks as channels to communicate with external stakeholders and defend themselves (Davis and Greve, 1997; Davis, Yoo, and Baker, 2003; Shane and Cable, 2002). This can help them divert blame when their firms encounter crises (Wiesenfeld et al., 2008), thus lowering the necessity for them to jump ship. In contrast, executives with lower levels of social capital have less communication channels and find it harder to avoid blame.

Fourth, it has been acknowledged that as executives' social capital increases, so does their ability to successfully bring about a turnaround. Executives' social capital provides their firms both access to external resources and signals of legitimacy and status (Adler and Kwon, 2002). These resources are particularly valuable for the turnaround process in declining firms (Daily and Dalton, 1995; Marcel and Cowen, 2014). Moreover, as social capital increases, so does the executive’s self-confidence (De Carolis and Saparito, 2006; Ryan et al., 2009). As such, executives with higher levels of social capital tend to be more confident about their capacity to rescue their firms, thus reducing the perceived necessity to jump ship. In contrast, executives with lower levels of social capital tend to have lower confidence that they can adequately address the crisis, thus increasing their desire to leave. 
Lastly, executive social capital tends to increase the opportunity costs of ship jumping. That is, executives not only benefit from their personal networks with external stakeholders as discussed above, but are also embedded in and constrained by those networks (Burt, 1992; Uzzi, 1997). By choosing to jump ship, executives may trigger these embeddedness constraints and thus incur significant socio-emotional costs (Carpenter et al., 2012; Uzzi, 1997). On the one hand, due to norms of reciprocity and mutual support, leveraging social capital to facilitate their ship-jumping behavior may put executives under social indebtedness (Blau, 1964; Vissa, 2011). Put differently, after executives ask for and receive favors from their social contacts, those who lend their support expect to have the favor repaid at some point. On the other hand, successfully jumping ship may sharply alter executives’ personal and professional identities (McArdle et al., 2007; Seibert et al., 2001), which may potentially disturb, undermine, or even destroy some valuable social ties with external stakeholders, leading to a depreciation of social capital (Fevre, 2000). These embeddedness constraints tend to be more salient for those who have more and stronger connections with external stakeholders, thus discouraging socially well-endowed executives from activating their social networks to facilitate ship-jumping.

In summary, executives with low levels of social capital have high desire to jump ship but less ability to do so due to their lack of awareness about and access to alternative job positions. As their social capital increases from low levels, executives will be better informed about and more capable of capturing alternative employment opportunities, thus becoming more likely to leverage their social capital to exit the declining firm and avoid the stigmatizing consequences should a failure occur. However, as social capital increases beyond a certain level it will also lower the executives’ perceived necessity of ship jumping and increase the opportunity costs of doing so due to the enhanced embeddedness effects, thus making executives 
with higher levels of social capital have better ability to leave but less desire to do so.

Additionally, at some point increasing social capital will not generate more external job opportunities. Taken together, this logic suggests that ship-jumping behavior will increase with increases in social capital until the cost-adjusted benefits from staying overcome the costadjusted benefits of leaving and the executive's ability to address the crisis becomes sufficient to sway the ship-jumping decision. In other words, the highest level of ship-jumping behavior should be observed at moderate levels of executive social capital, where executives have both the ability and the desire to leave. From this inflection point, we expect that ship-jumping behavior will decrease with increases in social capital as the protection effect discussed above increases. This suggests an inverted U-shaped relationship between executive social capital and shipjumping behavior, stated formally as follows.

Hypothesis 1: In declining firms, the level of an executive's social capital will have an inverted U-shaped association with the likelihood of the executive's ship-jumping behavior, such that executives with moderate levels of social capital are more likely to jump ship than those with high or low levels of social capital.

\section{Peer social capital and firm alliance networks in ship jumping}

As discussed above, by serving as the leading agents of their firms and occupying the particular positions, executives are embedded in the personal networks of their upper-echelons peers (i.e., peer social capital) and the firms’ alliance networks. Drawing on the network embeddedness perspective, we posit that these two firm-specific networks will affect executives' ship-jumping decisions by shaping the potential benefits and opportunity costs of the decisions.

Specifically, executives can establish important personal ties with other executives and directors with the shared time and mutual service through their ordinary job interactions (Granovetter, 1973). These upper-echelons ties create the opportunity for the focal executives and their peers to access each other’s personal networks. For example, executives can reach 
otherwise unconnected external stakeholders through the brokerage of their peers (Burt, 1992). As a result, the focal executives and their peers in the firm tend to be mutually embedded in each other's network structures. Likewise, by representing their firms in the interaction and communication of alliance networks, executives establish personal ties with contacts in partner firms (Nooteboom, Berger, and Noorderhaven, 1997; Zaheer, McEvily, and Perrone, 1998). Developed through interfirm interactions, these cross-boundary personal ties parallel the firms’ alliances and thus entrench executives into the positions of their firms in the broad alliance network (Carpenter et al., 2012; Jiang et al., 2014).

Executives' embeddedness in the two firm-specific networks has two-fold implications for their ship-jumping decisions. First, peer social capital and firm alliance networks both exert embeddedness constraints, deterring ship-jumping by increasing the opportunity costs of doing so. That is, by jumping ship from declining firms, executives lose important platforms and channels to communicate, interact, and cooperate with their upper-echelons peers and the representatives of partner firms, thus weakening (or even destroying) some of the personal ties they have developed through their ordinary job responsibilities. As a result, ship-jumping would disturb the mutual embeddedness between the focal executives and other peers and the firms' alliance partners. In other words, jumping ship may undermine the focal executives’ embeddedness in their peers’ personal networks and in their firms’ alliance networks, thus inevitably losing at least some of the relational investments (e.g., shared time, mutual services) that they have made in the firm-specific networks and potentially disturbing these networks (Jiang et al., 2014).

In this regard, peer social capital and firms’ alliance networks tend to limit ship-jumping behavior (Carpenter et al., 2012; Coleman, 1990). On the one hand, when peer social capital is 
high and firms' alliance networks are stronger, the executives face higher socio-emotional costs by jumping ship and sacrifice more significant relational investments they have made in these two well-developed firm-specific networks. On the other hand, socially well-endowed peers and firms with strong alliance networks can better leverage their social contacts to discourage or sanction the focal executives’ ship-jumping behavior (Jiang et al., 2014). For example, prior studies show that peers with high levels of social capital may be able to attribute discrediting events to the outgoing executives (Gamson and Scotch, 1964; Shen and Cho, 2005) and thus make them suffer from more depreciation in their legitimacy and status (Jiang et al., 2014). Taken together, the embeddedness constraints exerted by peer social capital and firms' alliance networks can lead to potentially significant opportunity costs of ship jumping.

Second, executives can personally benefit from their embeddedness within their peers’ personal networks and the alliance networks of their firms. As discussed, executives' reputations and status are tightly associated with the status of their firms and their personal contacts (Devers et al., 2009; Wiesenfeld et al., 2008). Executives can enhance their social status and legitimacy by being personally connected to peers with high levels of social capital (Westphal and Stern, 2006). Likewise, executives in central firms with abundant alliances in the industrial network can enjoy higher reputations and social status (Kim and Cannella, 2008; Palmer, Jennings, and Zhou, 1993; Zajac, 1988). The more prestigious and well-connected the peers and the firms, the more they can contribute to the focal executives’ personal influence and reputation. By exiting from firms with high levels of peer social capital and strong alliance networks, executives will inevitably sacrifice their access to these firm-specific networks, thus increasing the opportunity costs of ship jumping. In other words, when other executives and directors in their firms have abundant social capital and the firms have many alliance partners, it is harder for executives to 
find new jobs that can effectively compensate for the potential loss of access to current peer social capital and alliance networks.

Besides their embeddedness effects on the focal executives, high levels of peer social capital and strong alliance networks can also help firms emerge from their decline. As we noted above, it has been widely acknowledged that upper-echelons administrators' social network endowments reflect legitimacy and access to external resources (Hallen, 2008; Li and Zhang, 2007; Shane and Cable, 2002; Uzzi and Lancaster, 2004) and can help secure social support to deal with external uncertainties (Gulati, 1995; Uzzi, 1997). Likewise, alliances can also provide firms with access to external resources and support from their partners at relatively low cost and help stabilize their operations (Das and Teng, 2002; Hitt et al., 2000). These external resources and support are particularly valuable in helping declining firms restore their resource bases (Das, Sen, and Sengupta, 1998; Morrow et al., 2007). Following this logic, the declining firm can benefit from the social capital of peer executives and directors as well as its alliance network and enhance its likelihood of successfully reversing the decline. As the declining firm becomes more likely to survive the decline, the focal executive is less likely to be stigmatized by the firm, thus reducing both the potential benefits of, and the need to jump ship.

Taken together, we propose the following hypotheses:

Hypothesis 2: In declining firms, the level of an executive's peer social capital will be negatively associated with the executive's likelihood of jumping ship.

Hypothesis 3: In declining firms, the size of a declining firm's alliance network will be negatively associated with an executive's likelihood of jumping ship. 
Executive Ship Jumping in Declining Firms

\section{METHODS}

\section{Sample}

The specially treated public firms in the Chinese stock market provide a good setting to test our hypotheses. In May 2003, China launched the revised delisting risk-monitoring system, mandating that if a publicly-listed company reports accounting losses in two consecutive years, its stock will be classified as special treatment (ST) to warn investors about delisting risk. The “star-ST” (*ST) label is applied immediately after any listed company announces a loss for a second consecutive year and its stock is immediately listed with a “*ST" prefix (Jiang and Wang, 2008). ${ }^{*}$ ST stocks are subject to certain trading and financial restrictions. For example, the daily stock price movement for a *ST stock cannot exceed 5\% in either direction. Moreover, *ST firms are not allowed to raise additional capital from the stock market. After a stock is prefixed with $* \mathrm{ST}$, it will be suspended from public trading should the company report one more consecutive annual loss (three consecutive years), and the stock will be delisted after two more consecutive annual losses (four consecutive years). In contrast, a *ST company can remove the *ST status if its performance turns positive (even for a single year) after the *ST designation.

In sum, in the Chinese stock market, the *ST label indicates both the current decline of a company's performance and the high risk of its failure in the near future. As such, a company’s *ST designation is a strong and publicly accessible signal indicating decline (Zhou, 2014).

Moreover, since the *ST designation only occurs after two consecutive years of financial losses, it allows executives to proactively jump ship before the designation is attached. Taken together, these factors make the *ST setting a good context for our study.

We collected longitudinal data on 248 publicly-listed Chinese companies whose stock was prefixed with *ST (i.e., *ST companies) between 2004 and 2011, inclusive. The data were 
collected from two leading Chinese stock market data providers, i.e., WIND Information and CSMAR Solution. We excluded $126 *$ ST companies that experienced reverse mergers. A reverse merger or “Mai Ke (买壳)” in Chinese refers to the following practice. A private company takes control of a *ST company by buying its stock (usually $70 \%$ to $90 \%$ of outstanding shares), and then makes the decision for the *ST company to acquire the private firm. The private firm then has access to public capital in the stock market. It has been acknowledged that reverse mergers often lead to major changes in top management both before and after the *ST designation. However, executive turnover in target firms of reverse merger deals tends to have fundamentally different antecedents and is largely driven by the intentions of the acquirers rather than the voluntary choices of the executives (Darrough, Huang, and Zhao, 2014). As a result, including these reverse-merger firms would likely confound our hypotheses tests. This exclusion narrowed our sample size to $122 *$ ST firms. ${ }^{2}$

Following prior studies (Marcel and Cowen, 2014; Semadeni et al., 2008), for each *ST company, we examined the year-end reports identifying its senior executives, i.e., the CEO, CFO, president, and executive vice presidents as our sample executives. In total, this method led to a sample of 278 executives present in the report filed two years prior to the *ST designation.

\footnotetext{
${ }^{2}$ Since we selected $122 *$ ST firms out of the full set of $248 *$ ST firms by excluding all firms that experienced a reverse merger, it is necessary for us to address the potential for sample selection bias, where our major predictors may make certain *ST firms more likely to become the target of reverse mergers. Following prior studies, we applied Heckman's selection model (Heckman, 1979), calculating the inversed Mills ratio and use it to control for possible sample selection bias. Specifically, we first formulated a probit model using all the major firm-level independent variables in our model and a firm's experience since IPO to estimate the probability for each of the 248 sample *ST firms to become the target of a reverse merger. In this selection equation, a sample firm's experience since IPO served as an instrument that was not included in the final models. Then, we calculated the inversed Mills ratio using the following formula:

$$
\text { Inverse Mills ratio }{ }_{i}=\frac{\phi\left(p_{i}\right)}{\Phi\left(p_{i}\right)}
$$

where pi refers to the probability of *ST filing estimated from the probit model in the first step, $\phi\left(\mathrm{p}_{\mathrm{i}}\right)$ refers to the normal density of pi, and $\Phi\left(\mathrm{p}_{\mathrm{i}}\right)$ refers to the standard cumulative normal distribution for $\mathrm{p}_{\mathrm{i}}$. We then add the inverse Mills ratio to our models as a control variable in a sensitivity analysis. Results show that the effects of the inverse Mills ratio are insignificant in all of our statistical models, suggesting that our analyses do not suffer from sample selection bias. The results of the sensitivity analyses are available upon request.
} 


\section{Measures}

Ship-jumping behavior. We capture executives’ ship-jumping behavior as the proactive departure from the company in the two years prior to its *ST announcement. As we noted above, the *ST announcement is issued immediately following the release of a company's annual report revealing the second consecutive annual loss, which is commonly in the beginning of the fiscal year. As such, if the company received the *ST designation in year $N$, we used the annual report following the close of year $N-3$ as the baseline, extracting the names of top executives in the company's year-end report in year $N$-3, and comparing them with the names of the top management team members in year $N-2$ and year $N-1$ to identify sample executives' turnover events prior to the sample company’s *ST designation.

Importantly, not all executive turnover events we identified are due to a voluntary and proactive ship-jumping decision. Instead, declining companies may dismiss some executives for underperformance (e.g., Gamson and Scotch, 1964; Shen and Cho, 2005). As such, we strived to rule out involuntary turnover to ensure the robustness of our ship-jumping measure by adapting two criteria to identify executives’ ship-jumping behavior.

We first tracked the reemployment of sample executives, defining ship jumpers as those executives who took new executive positions within one year after they left a sample company. We used the database operated by a government-funded human-resource monitoring institute that focuses on business elites in public firms in China. According to the database, the average time for a former executive in a Chinese public firm to be reemployed as a senior executive is 2.2 years. Therefore, the significantly shorter reemployment period of the executives we 
identified as ship jumpers $(1 \text { year })^{3}$ indicates that they were likely engaged in a proactive search for new employment before departing and thus suffer less devaluation in the labor market, a central motivation for ship-jumping behavior (Semadeni et al., 2008). 108 of the 278 sample executives were reemployed as senior executives within 1 year after their departure.

Furthermore, we searched the newspaper database of The National Library of China to collect all reports about top executive turnover in the 122 sample *ST firms during a three-year period, i.e., from one year before to one year after the *ST designation. Following prior executive dismissal studies (e.g., Shen and Cannella, 2002; Wiersema and Zhang, 2011; Zhang, 2008), we adopted three criteria to better screen out forced or involuntary executive departure, classifying outgoing executives who were directly reported as being fired or forced out, resigning unexpectedly due to unspecified reasons, or taking unexpected early retirement as being dismissed. According to the search, the turnover of 62 executives was due to involuntary dismissal (16 reported as being fired, 42 reported as "resigning due to undisclosed personal reasons”, and 4 reported as “unexpected early retirement”). Among the 62 cases, 13 overlapped with the above sample of 108 executives located by the reemployment search.

By combining these two searches, we identified 95 of the 278 sample executives who engaged in ship-jumping. The dependent variable, ship jumping, was thus coded 1 in the year of exit, and otherwise coded 0. Among those executives who did not jump ship, 62 were dismissed, and the rest $(\mathrm{n}=121)$ stayed with their *ST firms during our observation window.

Executives’ social capital and peer social capital. Following prior studies (e.g., Marcel and Cowen, 2014), we measured executives’ social capital endowments for year $t$ as their

\footnotetext{
${ }^{3}$ We do not know how long an executive took to find his or her job in our sample. However, we do know that since they showed up on another firm's executive listing in the following year's end-of-year report, it was no longer than 1 year, implying that most of them moved immediately from the declining firm to a new employer.
} 
eigenvector centrality (log-transformed) within the board-interlock network across all directors in year $t-1$. It has been noted that the board interlock network across Chinese public firms is dense relative to US and UK board networks due to the smaller number and larger size of public firms in China (Jiang et al., 2014; Jiang and Jin, 2010). As a result, compared to executives in public firms in the United States, senior executives in Chinese public firms generally have more opportunities to serve as outside directors. In this interlocking directorship network, executives connect with other directors by serving on the same board (excluding the tie achieved through their own company). Comparing with degree centrality, a measure that mainly captures the number of ties that an executive maintains, eigenvector centrality accounts for the importance of different social contacts, weighting the ties with well-connected contacts more heavily (Bonacich, 1987; Carpenter et al., 2012). Similarly, we operationalized peer social capital as the average of the logged eigenvector centrality of all other executives and directors in the company. These calculations were conducted using UCINET 6.

Alliance network. The size of a sample firm's alliance network in year $t$ was operationalized as the number of alliances the firm was engaged in during year $t-1$, adjusted based on the average number of alliances engaged in by all public firms in the firm's industry. Control variables. Our analyses controlled for a series of executive- and firm-level characteristics that may potentially influence ship jumping. For executives’ personal characteristics, we controlled for their age, education ( 5 for doctoral degree, 4 for masters, 3 for undergraduate, 2 for high school, and 1 for otherwise), gender, tenure in the current position, compensation, and executive shareholding (the proportion of outstanding shares they owned). Following prior studies (e.g., Semadeni et al., 2008), we also created three binary variables for executive titles to control for the different effects of hierarchical level. The variable $C E O$ was 
coded 1 if the executive was the CEO in the sampled *ST firm and 0 otherwise. The variable board chair was coded 1 if the executive served as the chairman of the board in the sampled *ST firm and 0 otherwise. The variable other inside director was coded 1 if the executive served as a director (not board chair) in the sampled *ST firm and 0 otherwise. For firm-level features, we controlled for our sample firms’ age, assets, board size, performance (ROA), and ownership type (1 for state-owned, 0 for otherwise).

Industry membership may systematically affect executives’ ship-jumping behavior. To guard against problems arising from unobserved heterogeneity, we created a series of industry dummy variables and incorporated them in all of our analyses. Following the similar logic, we also created and incorporated a series of annual dummy variables (Certo and Semadeni, 2006). To save space, we do not report the coefficients from the industry dummies and annual dummies.

Moreover, to further ensure the robustness of our analysis, we conducted the Durbin-WuHausman ( $D W H)$ test (i.e., the augmented regression test) for our major predictors to evaluate whether endogeneity is an issue (c.f., Davidson and MacKinnon, 1993). DWH test includes the residuals of each potential endogenous predictors, as a function of the instrumental variables and all exogenous variables, in a regression of the original model. We used the executives' degree centrality in the board interlock network, and the firms’ experience since IPO as instrumental variables to conduct the DWH test. Results confirmed the exogeneity of our three major predictors, showing that endogeneity is unlikely to be of concern in our analyses. The results of these tests are available from the authors upon request.

\section{Method of Analysis}

Because our observation window is finite (2 years prior to *ST filing), our data are right censored (Allison, 1999). In this situation, using logit models to model binary outcomes may 
yield downwardly-biased estimates (Tuma and Hannan, 1984). To avoid this right censoring problem, we used an event-history analysis to model the likelihood of executive ship jumping. The event-history analysis models the hazard rate, which is the likelihood that an executive will jump ship at time $t$, given that the executive has not jumped ship before $t$ (Allison, 1999; Richards, 1929). Our estimates are all derived from the following Cox proportional hazards regression model (Cox, 1972):

$$
h_{i}(t)=h_{0}(t) \times \exp \left\{\sum \beta_{k} \times\left[X_{i k}(t)\right]\right\}
$$

where $\mathrm{h}_{0}(\mathrm{t})$ refers to the baseline hazard function, and $\mathrm{X}_{\mathrm{ik}}(\mathrm{t})$ refers to the value of the $k$ th independent variable for actor $i$ at time $t$. A central assumption is proportionality (Cox, 1972; Fine and Gray, 1999), meaning that the hazard for any individual is a fixed proportion of the hazard for any other individual in the sample. We tested this assumption using the stphtest command in STATA 14. Results showed no significant violation of the proportionality assumption.

We also clustered observations based on firm ID to correct for potential correlation among observations from the same firm (Wooldridge, 2002). The robust-clustered standard error calculation, which is a generalization of the sandwich method of calculating heteroskedasticityrobust standard errors (Baum, Nichols, and Schaffer, 2010), also helps address concerns about firm-level heteroscedasticity.

\section{RESULTS}

Table 1 provides means, standard deviations, and correlations. We calculated variance inflation factors (VIFs) for all models in our analyses. Results show that the average VIF value 
was 3.25 (the maximum VIF was 4.09), indicating that multicollinearity is unlikely to be of concern.

Insert Tables 1 and 2 About Here

Table 2 reports the results of the event-history analyses. Model 1 provides the baseline model including only control variables. Model 2 is the fully specified model that includes the three theoretical variables. In the first column of each model, we report odds ratios, which represent the proportional change in hazard rate from a one-unit increase in the independent variable (Allison, 1999; Richards, 1929). The second column of each model reports Z-scores calculated with robust-clustered standard errors. We report Z-scores to help better demonstrate the direction of each odds ratio, i.e., increasing or decreasing the hazard rate.

Hypothesis 1 posits that executives' social capital endowments have an inverted Ushaped relationship with their ship-jumping behavior, such that executives are less likely to jump ship when their social capital endowments are particularly low or particularly high. This hypothesis is supported by the evidence reported in Model 2. The odds ratio of executive social capital is $3.43(\mathrm{z}=6.17, \mathrm{p}<.001)$, and the odds ratio of the executive social capital squared is 0.16 $(\mathrm{z}=-5.40, \mathrm{p}<.001)$. The interaction is plotted in Figure 1.

We also checked the robustness of this curvilinear relationship. That is, following the suggestions of Haans and colleagues (2015), we split the data into two parts based on the inflection point (executive social capital=2.65), which falls between the high (mean + standard deviation, $2.72+0.55=3.27$ ) and low value (mean - standard deviation, $2.72-0.55=2.17)$ of executive social capital. We then check the coefficients for both ends. Results show that executive social capital is significantly related to ship jumping in both subsamples. The low-end subsample indicates a positive relationship between executive social capital (odds ratio=5.41, 
$\mathrm{z}=26.07, \mathrm{p}<.001$ ), while the high-end subsample demonstrates a negative relationship (odds ratio $=0.20, \mathrm{z}=-7.37, \mathrm{p}<.001)$. Taken together, these results confirm the inverted U-shaped effect of executives’ social capital on their ship-jumping decision.

\section{Insert Figure 1 About Here}

Hypothesis 2 predicts that peer social capital will reduce the likelihood of ship jumping. The evidence from Model 2 supports this hypothesis. The odds ratio for peer social capital is $0.67(\mathrm{z}=-3.38, \mathrm{p}=.001)$, indicating that a one-unit increase in peer social capital is associated with a 33\% reduction in the hazard rate of executive ship-jumping (1 - 0.67).

Hypothesis 3 predicts that the firm’s alliance network will reduce the likelihood of ship jumping. The evidence from Model 2 also supports this hypothesis. The odds ratio for the size of alliance network is $0.78(\mathrm{z}=-2.69, \mathrm{p}=.007)$, indicating that increasing alliance network size by one unit is associated with a $22 \%$ reduction in the hazard rate of ship jumping $(1-0.78)$.

With respect to our significant control variables, Model 1 shows that in declining firms, the hazard rate of ship jumping is reduced for executives who are older (odds ratio=0.50, $\mathrm{p}<.001$ ) and have served shorter tenures in the current position (odds ratio=1.05, $\mathrm{p}=.011$ ), and the hazard rate is increased for firms with larger board (odds ratio=1.06, $\mathrm{p}=.023$ ). Also, *ST firms’ performance is negatively associated with executives' ship-jumping efforts (odds ratio=0.29, $\mathrm{p}=.001)$

\section{Robustness check: Ship jumping versus dismissal}

Notably, it has been widely noted that when facing severe organizational decline, firms may choose to actively “clean house” and dismiss their top executives (Finkelstein et al., 2009; Marcel and Cowen, 2014; Shen and Cho, 2005). On the one hand, dismissing executives who are perceived as responsible for the underperformance can signal the firm’s intention to 
acknowledge past mistakes and to remedy shortcomings, thus helping to recover the firm's credibility (D'Aveni, 1994). On the other hand, the change of top executives also potentially stimulates the declining firm to launch new turnaround strategies (Daily and Dalton, 1995). Given the prevalence of this "house cleaning" effect in declining firms, it may be helpful for us to specifically distinguish the involuntary executive turnover due to dismissal from the voluntary executive ship jumping. To do so, we conducted a sensitivity analysis to further gauge the robustness of our major findings and validate our conclusions.

We contrasted executive ship jumping and dismissal with competing-risk regression (Fine and Gray, 1999). Competing risks refer to contexts and settings involving two or more mutually exclusive failure events, the joint distribution of which over time cannot be accurately estimated using regular survival models due to the possible covariate effects between the competing events (Gray, 1988). To analyze these competing risks, Fine and Gray (1999) introduced a competing-risk regression approach based on subdistribution hazard function of a failure event of interest. The subdistribution hazard for a failure event of interest $k$ is defined as the probability that a subject fails from cause $k$ at time $t$, given the subject did not experience the same failure before $t$ (i.e., did not experience any type of failure or experienced a different type of failure than $k$ ). As such, individuals who failed before $t$ but not due to the failure event of interest $(k)$ remain in the risk set for all future time points. Accordingly, the cumulative incidence function of the failure event of primary interest can be estimated directly from the regression coefficients without modeling the covariates between competing failure events (Haller, Schmidt, and Ulm, 2013).

In our case, executive ship jumping and dismissal are the two competing failure events. Based on the coding process for ship jumping described above, we constructed a categorical 
variable, executive employment status, which was coded 1 for each executive at the year of ship jumping, 2 at the year of being dismissed, and 0 otherwise (retention). We then used the stcrreg command in STATA 14 to conduct competing-risk regression with all predictors in our main Cox survival model (see Model 2 of Table 2). Appendix 1 reports the results of this sensitivity analysis. Model 1 analyzes executive ship jumping as the failure event of interest and executive dismissal as the competing event. Model 2 analyzes executive dismissal as the failure event and retention as the competing event. Model 3 analyzes executive dismissal as the failure event and retention as the competing event. In the first column of each model, we report the subdistribution hazard ratios (SHRs for short) and the standard errors. The second column of each model reports Z-scores in order to help better demonstrate the direction of each SHR, i.e., increasing or decreasing the hazard rate.

Results in Model 1, which contrasts executive ship jumping with dismissal, show high consistency with our primary analysis. The SHR for executive social capital is 3.55 ( $\mathrm{z}=6.84$, $\mathrm{p}<.001$ ), and the SHR of the executive social capital squared is $0.15(\mathrm{z}=-6.03, \mathrm{p}<.001)$, thus supporting the prediction of Hypothesis 1 about the inverted U-shaped effect of executive social capital on ship jumping. Moreover, peer social capital (SHR=0.74, z=-3.12, $\mathrm{p}=.002$ ) and firm alliance network (SHR=0.76, $\mathrm{z}=-3.10, \mathrm{p}=.002)$ are both negatively related to the likelihood of executive ship jumping, supporting Hypotheses 2 and 3. As such, the competing risk contrast between executive ship jumping and dismissal largely confirms our main conclusions.

Likewise, the competing risk contrast between executive ship jumping and retention also effectively replicates our main results. According to Model 2, the SHR for executive social capital is $4.13(\mathrm{z}=5.78, \mathrm{p}<.001)$, and the SHR for executive social capital squared is 0.11 ( $\mathrm{z}=-$ 5.13, $\mathrm{p}<.001$ ), showing the inverted U-shaped effect on ship jumping. Also, both peer social 
capital (SHR=0.69, z=-2.79, p=.005) and firm alliance network (SHR=0.69, z=-2.84, p=.005)

discourage ship jumping. In contrast, according to Model 3, which compares executive dismissal with retention, these network predictors (i.e., executive social capital, peer social capital, and firm alliance network), only show negligible effects on executive dismissal.

Further, according to Model 3, executives who are older (SHR=3.05, z=3.66, $\mathrm{p}=.001$ ), male (SHR=0.26, $\mathrm{z}=-3.34, \mathrm{p}=.002)$, and have shorter tenures $(\mathrm{SHR}=0.61, \mathrm{z}=-7.38, \mathrm{p}<.001)$ are more likely to be dismissed in declining firms. Also, board chairs (SHR=0.13, $\mathrm{z}=-3.88, \mathrm{p}=.001$ ) and CEOs (SHR=0.00, $\mathrm{z}=-28.14, \mathrm{p}<.001)$ are less likely to experience executive dismissal. Meanwhile, financial performance is negatively related to executive dismissal (SHR=0.00, z=7.07, $\mathrm{p}<.001$ ). Lastly, state-owned firms are more likely to dismiss their executives when encountering decline $(\mathrm{SHR}=6.55, \mathrm{z}=4.41, \mathrm{p}<.001)$. In contrast, Model 2 shows that these variables have either negligible or opposite effects on executive ship jumping, except for firm performance $(\mathrm{SHR}=0.29, \mathrm{z}=-2.30, \mathrm{p}=.02)$.

Taken together, these results of sensitivity analyses show that our major predictors have systematically different effects across “ship jumpers” and dismissed executives, thus effectively differentiating the mechanisms behind executive dismissal from those behind ship jumping and ruling out the potential confounding effect of the so-called "house cleaning” effect (c.f., Marcel and Cowen, 2014). Moreover, the contrast between ship jumpers and executives who remain in the current firm demonstrates the same systematic differences, thus largely confirming the robustness of both our methodologies and conclusions.

\section{DISCUSSION}

Drawing on a network embeddedness perspective, we used a cost-benefit approach to explore the specific benefits and opportunity costs associated with ship-jumping by executives in 
declining firms. On the one hand, executives can be motivated to proactively escape from firms with declining performance because they may be personally stigmatized by the failure (Semadeni et al., 2008). On the other hand, jumping ship can also incur personal costs for the outgoing executives, such as the loss of access to the valuable resources possessed by the declining firms (Perry, 1984). The benefits and opportunity costs of ship-jumping behaviors together present an interesting dilemma for executives in declining firms.

Our study complements and extends research on executive turnover by focusing on the ship-jumping behavior of executives - that is, exit from the declining firm to accept reemployment elsewhere before performance problems become publicly known. More broadly, we shed light on the topic of voluntary executive turnover in declining firms. Although declining performance has been widely acknowledged as a central reason behind executive turnover, prior studies have predominantly emphasized involuntary executive turnover in these declining firms. So far, with few exceptions (e.g., Semadeni et al., 2008), little effort has been devoted to highlighting how executives in declining firms voluntarily and proactively make shipjumping decisions. As insiders deeply embedded in their firms, executives may base their shipjumping choices on different considerations than directors. For example, directors can simultaneously serve on multiple boards, while executive positions are generally full time and exclusive. Therefore, the ship-jumping behavior of executives may be more confined. Against this backdrop, we strive to highlight the decision mechanism behind executives’ ship-jumping behavior and explore its implications.

Drawing on a network embeddedness perspective (Granovetter, 1985), our research considers the way in which executives' networks within and beyond their declining firms affect their ship-jumping decisions, thus helping to resolve the cost-benefit dilemma. The evidence 
from *ST public firms in China largely confirmed our main predictions. With regard to the external network, we highlight the effect of an essential construct-executive social capital. It has been acknowledged that executives' social capital can serve as a buffering mechanism that mitigates the negative personal impact of firm-level crises on executives (Wiesenfeld et al., 2008; Zajonc, 1980). Accordingly, executives with high social capital endowments rely less on ship jumping to avoid stigmatization by the current firm. Meanwhile, executives’ social capital also determines the feasibility of their external employment opportunities (Dess and Shaw, 2001). While a low network endowment increases the need for an executive to jump ship, it also restricts the available opportunities to do so. Our findings confirm the inverted U-shaped relationship between executives' social capital and their ship-jumping behavior.

Meanwhile, executives are also embedded in internal networks with their upper-echelons peers (i.e., the intra-firm upper-echelon network) and their firms' alliance networks (Carpenter et al., 2012; Gulati and Westphal, 1999). As such, we have labeled these two networks as executive peer social capital and the firm's alliance network. Our results show that the two firmspecific networks benefit executives and discourage ship jumping.

Through the perspective of network multiplexity (Carpenter et al., 2012; Ferriani, Fonti, and Corrado, 2015; Lomi and Pattison, 2006; Shipilov et al., 2014), when an actor is embedded in multiple different networks, the embeddedness influences of these networks may potentially interact with each other. Drawing on this insight, we explore the possibility that the influences of executives' personal networks with external stakeholders and the two firm-specific networks might interact with each other in determining executives' decisions. Cox regression results show that the negative effect of peer social capital (interaction term odds ratio $=0.44, \mathrm{z}=-3.96, \mathrm{p}<.001$ ) and firms' alliance network (interaction term odds ratio $=0.54, \mathrm{z}=-2.01, \mathrm{p}=.045$ ) are both 
strengthened by executive social capital. As discussed, both peer social capital and firms' alliance networks can provide benefits to and exert constraints on executives due to network embeddedness effects. Accordingly, jumping ship from a declining firm, which may potentially disturb the executives' embeddedness in the two firm-specific networks, can trigger certain costs and lead to the loss of certain benefits for the executives, thus discouraging ship jumping. In this regard, the above results suggest that the embeddedness influences of peer social capital and firms' alliance networks on executives become stronger as the level of executive social capital increases. It may be that high levels of social capital allow socially well-endowed executives to better connect to their own personal contacts as well as the contacts of their peers and their firms (Burt, 2000; Shipilov et al., 2014), thus heightening the extent to which the focal executives' personal networks and the two firm-specific networks are mutually entrenched with each other. Such enhanced network multiplexity effects might deepen the focal executives' embeddedness in their peers' personal networks and their firms' alliance networks.

Our research also seeks to make the following major contributions. First, our findings have important theoretical implications for declining firms based on a better understanding of their executives. Executives in declining firms often face the dilemma we outlined here: they may use their social capital, albeit with some risk, to halt and reverse the decline. However, should they fail to reverse the decline, they risk being personally stigmatized, leading to financial and reputational losses. Executives must avoid affiliating with discredited organizations and events in order to avoid the risk of stigmatization, and stigmatized executives are thereby constrained in their ability for further career development. Thus, executives in declining firms may use their social capital to search for ship-jumping opportunities. We contribute to the 
strategic leadership literature by highlighting the decision mechanisms behind executives' shipjumping behavior in declining firms.

This reasoning also provides important practical implications. It shows that declining firms may rely more on executives with low or high social capital to turn the decline around as the central benefit of ship-jumping behavior is for executives to avoid being personally stigmatized by their firms (Semadeni et al., 2008). Moreover, the benefits of ship jumping rest upon the potential opportunity costs associated with the action. Thus, firms may take actions to enhance the success of a turnaround, which may increase the confidence of executives and encourage them to tie their reputations to their firms.

Second, we contribute to social capital research by providing a more complete understanding about the implications of executive social capital and highlighting the boundary conditions of its benefits (Acquaah, 2007; Peng and Luo, 2000). It has been widely acknowledged in strategic leadership research that top executives’ social capital can significantly benefit their firms (Carpenter et al., 2012; Li and Zhang, 2007). Following this insight, researchers have tended to assume that executives' social capital is widely available to their firms. However, our findings point out that this argument is likely to be incomplete. Executives may also use their personal social-capital endowments to serve their own best interests, particularly when the firms and the executives have significant conflicts of interests. As such, it may be incomplete to unconditionally assume that executive social capital is a firm-level resource. Using the instance of executives’ ship-jumping behavior in declining firms, we highlight that executives may not always use their social capital to benefit their firms; instead, they may use it to find alternative employment opportunities. 
Our study has limitations on which future research can build. First, our study highlights social network theory to understand the ship-jumping behavior of executives. However, other theories also provide useful insights that highlight different decision mechanisms behind executive ship-jumping. In this regard, future research can benefit from embracing other theoretical perspectives by contrasting and integrating them with our current approach.

Moreover, future research may benefit from further exploring the inverted U-shaped relationship between executive social capital and ship jumping. Particularly, the non-monotonic relationship that we observed may suggest variance in the marginal effects of executives' social capital on their job search and turnover decisions. As pointed out by prior comprehensive reviews (e.g., Carpenter et al., 2012; Lin, 2001), exploring such changes in the marginal effects of social capital can help shed extra light on the underlying mechanisms behind the important implications of social networks, thus effectively complementing the extant social network and social capital literatures.

Lastly, future studies can benefit from exploring the connections between the shipjumping behaviors of executives and directors, i.e., insiders and outsiders. We show that executive ship-jumping behavior is affected by peer directors' social capital endowments. This may suggest that the ship-jumping behavior of executives and the exit behavior of directors have potential connections. Future research may benefit from contrasting the decision mechanisms of executives and directors and highlighting their potential connections. 


\section{REFERENCES}

Acquaah M. 2007. Managerial social capital, strategic orientation, and organizational performance in an emerging economy. Strategic Management Journal 28(12): 12351255.

Adler PS, Kwon S-W. 2002. Social capital: Prospects for a new concept. Academy of Management Review 27(1): 17-40.

Ahuja G, Polidoro F, Mitchell W. 2009. Structural homophily or social asymmetry? The formation of alliances by poorly embedded firms. Strategic Management Journal 30(9): 941-958.

Allison PD. 1999. Logistic regression using SAS: Theory and applications. SAS Publishing: Carey, NC.

Baum CF, Nichols A, Schaffer ME. 2010. Evaluating one-way and two-way cluster-robust covariance matrix estimates. Paper presented at the BOS10 Stata Conference, Boston, MA.

Belliveau MA, O'Reilly CA, III, Wade JB. 1996. Social capital at the top: Effects of social similarity and status on CEO compensation. Academy of Management Journal 39(6): 1568-1593.

Blau PM. 1964. Exchange and power in social life. Wiley: New York.

Boeker W. 1992. Power and managerial dismissal: Scapegoating at the top. Administrative Science Quarterly 27: 538-547.

Boivie S, Graffin SD, Pollock TG. 2012. Time for me to fly: Predicting director exit at large firms. Academy of Management Journal 55(6): 1334-1359.

Bonacich P. 1987. Power and centrality: A family of measures. American Journal of Sociology 92(5): 1170-1182.

Burt RS. 1992. Structural holes: The social structure of competition. Harvard University Press: Cambridge, MA.

Burt RS. 2000. The network structure of social capital. In Research in organizational behavior. Staw BM, Sutton RI (eds.), JAI Press: Greenwich, CT.

Carmeli A. 2003. The relationship between emotional intelligence and work attitudes, behaviour and outcomes: An examination among senior managers. Journal of Managerial Psychology 18(8): 788-813.

Carpenter MA, Geletkanycz MA, Sanders WG. 2004. The upper echelons revisited: Antecedents, elements, and consequences of top management team composition. Journal of Management 60(6): 749-778.

Carpenter MA, Li M, Jiang H. 2012. Social network research in organizational contexts: A systematic review of methodological issues and choices. Journal of Management.

Carpenter MA, Sanders WG, Gregersen HB. 2001. Bundling human capital with organizational context: The impact of international assignment experience on multinational firm performance and CEO pay. Academy of Management Journal 44(3): 493-511.

Castanias RP, Helfat CE. 1991. Managerial resources and rents. Journal of Management 17(1): 155-171.

Certo ST, Semadeni MB. 2006. Strategy research and panel data: Evidence and implications. Journal of Management 32(3): 449-471.

Coleman JS. 1990. Foundations of social theory. Harvard University Press: Cambridge, MA. 
Cox DR. 1972. Regression models and life-tables. Journal of the Royal Statistical Society 34(2): 187-200.

D'Aveni RA. 1990. Top managerial prestige and organizational bankruptcy. Organization Science 1: 121-142.

D'Aveni RA. 1994. Hypercompetition: Managing the dynamics of strategic maneuvering. The Free Press: New York.

Daily CM, Dalton DR. 1995. CEO and director turnover in failing firms: An illusion of change? Strategic Management Journal 16(5): 393-400.

Darrough MN, Huang R, Zhao S. 2014. The spillover effect of fraud allegations against Chinese reverse mergers. Available at SSRN: $\underline{\text { http://ssrn.com/abstract }=2144483 .}$.

Das S, Sen PK, Sengupta S. 1998. Impact of strategic alliances on firm valuation. Academy of Management Journal 41(1): 27-41.

Das TK, Teng B-S. 2002. Alliance constellations: A social exchange perspective. Academy of Management Review 27(3): 445-456.

Davidson R, MacKinnon JG. 1993. Estimation and inference in econometrics. Oxford University Press: New York.

Davis GF, Greve HR. 1997. Corporate elite networks and governance changes in the 1980s. American Journal of Sociology 103(1): 1-37.

Davis GF, Yoo M, Baker WE. 2003. The small world of the American corporate elite, 19822001. Strategic Organization 1(3): 301-326.

De Carolis DM, Saparito P. 2006. Social capital, cognition, and entrepreneurial opportunities: A theoretical framework. Entrepreneurship Theory and Practice 30(1): 41-56.

Dess GG, Shaw JD. 2001. Voluntary turnover, social capital, and organizational performance. Academy of Management Review 26(3): 446-456.

Devers CE, Dewett T, Mishina Y, Belsito CA. 2009. A general theory of organizational stigma. Organization Science 20(1): 154-171.

Fei X. 1992. From the soil: The foundations of Chinese society. University of California Press: Berkeley, CA.

Ferriani S, Fonti F, Corrado R. 2015. The social and economic bases of network multiplexity: Exploring the emergence of multiplex ties. Strategic Organization 11(1): 7-34.

Fevre R. 2000. Socialising social capital: identity and the transition to work and economic development. In Social capital: Critical perspectives. Baron S, Field J, Schuller T (eds.), Oxford University Press: Oxford, UK.

Fine JP, Gray RJ. 1999. A proportional hazards model for the subdistribution of a competing risk. Journal of the American Statistical Association 94(446): 496-509.

Finkelstein S, Hambrick DC, Cannella AA, Jr. 2009. Strategic leadership: Theory and research on executives, top management teams, and boards. Oxford University Press: Oxford, UK.

Gamson WA, Scotch NA. 1964. Scapegoating in baseball. American Journal of Sociology 70: 69-72.

Giordano PC. 1983. Sanctioning the high-status deviant: An attributional analysis. Social Psychology Quarterly 46(4): 329-342.

Goffman E. 1963. Stigma: Notes on the management of spoiled identity. Prentice-Hall: Englewood Cliffs, N.J.

Granovetter M. 1973. The strength of weak ties. American Journal of Sociology 78(6): 13601380. 
Granovetter M. 1985. Economic action and social structure: The problem of embeddedness. American Journal of Sociology 91: 481-510.

Gray RJ. 1988. A class of KK-sample tests for comparing the cumulative incidence of a competing risk. Annals of Statistics 16(2): 1141-1154.

Gulati R. 1995. Social structure and alliance formation patterns: A longitudinal analysis. Administrative Science Quarterly 40(4): 619-652.

Gulati R, Gargiulo M. 1999. Where do interorganizational networks come from? American Journal of Sociology 104(5): 1439-1493.

Gulati R, Westphal JD. 1999. Cooperative or controlling? The effects of CEO-board relations and the content of interlocks on the formation of joint ventures. Administrative Science Quarterly 44(3): 473-506.

Hallen BL. 2008. The causes and consequences of the initial network positions of new organizations: From whom do entrepreneurs receive investments? Administrative Science Quarterly 53(4): 685-718.

Haller B, Schmidt G, Ulm K. 2013. Applying competing risks regression models: an overview. Lifetime Data Analysis 19(1): 33-58.

Hambrick DC, Geletkanycz MA, Fredrickson JW. 1993. Top executive commitment to the status quo: Some tests of its determinants. Strategic Management Journal 14(6): 401-418.

Hayward MLA, Shepard DA, Griffin D. 2006. A hubris theory of entrepreneurship. Management Science 52(2): 160-172.

Heckman JJ. 1979. Sample selection bias as a specification error. Econometrica 47(1): 153-161.

Hitt MA, Dacin MT, Levitas E, Arregle J-L, Borza A. 2000. Partner selection in emerging and developed market contexts: Resource-based and organizational learning perspectives. Academy of Management Journal 43(3): 449-467.

Hollander EP. 1958. Conformity, status, and idiosyncrasy credit. Psychological Review 65(2): 117-127.

Jiang G, Wang H. 2008. Should earnings thresholds be used as delisting criteria in stock market? Journal of Accounting and Public Policy 27(5): 409-419.

Jiang H, Cannella AA, Jr., Gao L, Jiao J. 2014. Inward-outward guanxi contagion and employees’ responses to managerial guanxi practices. Journal of Management and Organization 19(5): 613-634.

Jiang H, Jin Z-M. 2010. How members' managerial social capital influences their opportunism in interfirm relationships: Empirical investigation of Chinese - foreign joint ventures. Nankai Business Review International 1(2): 180-196.

Kang J-K, Shivdasani A. 1995. Firm performance, corporate governance, and top executive turnover in Japan. Journal of Financial Economics 38(1): 29-58.

Kim Y, Cannella AA, Jr. 2008. Towards a social capital theory of director selection. Corporate Governance: An International Review 16(4): 282-293.

Levin DZ, Walter J, Murnighan JK. 2011. Dormant ties: The value of reconnecting. Organization Science 22(4): 923-939.

Li H, Zhang Y. 2007. The role of managers' political networking and functional experience in new venture performance: Evidence from China's transition economy. Strategic Management Journal 28(8): 791-804.

Lin N. 2001. Social capital. Cambridge University Press: Cambridge, MA.

Lin Z, Yang H, Arya B. 2009. Alliance partners and firm performance: Resource complementarity and status association. Strategic Management Journal 30(9): 921-940. 
Lipsey RG, Steiner PO. 1975. Economics. Harper-Collins: New York.

Lomi A, Pattison P. 2006. Manufacturing relations: An empirical study of the organization of production across multiple networks. Organization Science 17(3): 313-332.

Marcel JJ, Cowen AP. 2014. Cleaning house or jumping ship? Understanding board upheaval following financial fraud. Strategic Management Journal 35(6): 926-937.

McArdle S, Waters L, Briscoe JP, Hall DT. 2007. Employability during unemployment: Adaptability, career identity and human and social capital. Journal of Vocational Behaviour 71: 247-264.

Meindl JR, Ehrlich SB. 1987. The romance of leadership and the evaluation of organizational performance. Academy of Management Journal 30(1): 91-109.

Morrow JL, Sirmon DG, Hitt MA, Holcomb TR. 2007. Creating value in the face of declining performance: Firm strategies and organizational recovery. Strategic Management Journal 28(3): 271-283.

Nelson DL, Burke RJ. 2000. Women executives: Health, stress, and success. Academy of Management Executive 14(2): 107-121.

Nooteboom B, Berger H, Noorderhaven NG. 1997. Effects of trust and governance on relational risk. Academy of Management Journal 40(2): 308-338.

Palmer DA, Jennings PD, Zhou X. 1993. Late adoption of the multidivisional form by large U.S. corporations: Institutional, political, and economic accounts. Administrative Science Quarterly 38: 100-131.

Peng MW, Luo Y. 2000. Managerial ties and firm performance in a transition economy: The nature of a micro-macro link. Academy of Management Journal 43(3): 486-501.

Perry LT. 1984. Key human resource strategies in an organization downturn. Human Resource Management 23(1): 61-75.

Pfeffer J, Salancik GR. 1978. The external control of organizations: a resource dependence perspective. Harper \& Row: New York.

Pozner J-E. 2008. Stigma and settling up: An integrated approach to the consequences of organizational misconduct for organizational elites. Journal of Business Ethics 80(1): 141-150.

Richards RD. 1929. The early history of banking in England. P. S. King \& Son, Ltd.: London.

Rogan M. 2014. Executive departures without client losses: The role of multiplex ties in exchange partner retention. Academy of Management Journal 57(2): 563-584.

Ryan L, Sales R, Tilko M, Siara B. 2009. Family strategies and transnational migration: Recent Polish migrants in London. Journal of Ethnic and Migration Studies 35(1): 61-77.

Seibert SE, Kraimer ML, Liden RC. 2001. A social capital theory of career success. Academy of Management Journal 44(2): 219-237.

Semadeni MB, Cannella AA, Jr., Fraser DR, Lee DS. 2008. Fight or flight: Managing stigma in executive careers. Strategic Management Journal 29(3): 557-567.

Shane S, Cable D. 2002. Network ties, reputation, and the financing of new ventures. Management Science 48(3): 364-381.

Shen W, Cannella AA, Jr. 2002. Power dynamics within top management and their impacts on CEO dismissal followed by inside succession. Academy of Management Journal 45(6): 1195-1208.

Shen W, Cho TS. 2005. Exploring involuntary turnover through a managerial discretion framework. Academy of Management Review 30(4): 843-854. 
Shipilov A, Gulati R, Kilduff M, Li S, Tsai W. 2014. Relational pluralism within and between organizations. Academy of Management Journal 57(2): 449-459.

Singh H. 1993. Challenges in researching corporate restructuring. Journal of Management Studies 30(1): 147-172.

Smith EB, Menon T, Thompson L. 2012. Status differences in the cognitive activation of social networks. Organization Science 23(1): 67-82.

Snijders TAB, van de Bunt GG, Steglich CEG. 2010. Introduction to actor-based models for network dynamics. Social Networks 32(1): 44-60.

Sonenshein S. 2007. The role of construction, intuition, and justification in responding to ethical issues at work: The sensemaking-intuition model. Academy of Management Review 12(4): 1022-1040.

Tuma NB, Hannan MT. 1984. Social dynamics: Models and methods. Academic Press: New York.

Uzzi B. 1997. Social structure and competition in interfirm networks: The paradox of embeddedness. Administrative Science Quarterly 42(1): 35-67.

Uzzi B, Lancaster R. 2004. Embeddedness and price formation in the corporate law market. American Sociological Review 69(3): 319-344.

Vissa B. 2011. A matching theory of entrepreneurs' tie formation intentions and initiation of economic exchange. Academy of Management Journal 54(1): 137-158.

Watts DJ. 1999. Networks, dynamics, and the small-world phenomenon. American Journal of Sociology 105(2): 493-527.

Weick KE. 1995. Sensemaking in organizations. Sage Publications: Thousand Oaks.

Westphal JD, Stern I. 2006. The other pathway to the boardroom: How interpersonal influence behavior can substitute for elite credentials and demographic majority status in gaining access to board appointments. Administrative Science Quarterly 51(2): 169-204.

Wiersema M, Zhang Y. 2011. CEO dismissal: The role of investment analysts. Strategic Management Journal 32(11): 1161-1182.

Wiersema MF. 2002. Holes at the top: Why CEO firings backfire. Harvard Business Review December.

Wiesenfeld BM, Wurthmann K, Hambrick DC. 2008. The stigmatization and devaluation of elites associated with corporate failures: A process model. Academy of Management Review 33(1): 231-251.

Wooldridge JM. 2002. Econometric analysis of cross section and panel data. MIT Press: Cambridge, MA.

Zaheer SA, McEvily B, Perrone V. 1998. Does trust matter? Exploring the effects of interorganizational and interpersonal trust on performance. Organization Science 9(2): 141-159.

Zajac EJ. 1988. Interlocking directorates as an interorganizational strategy: A test of critical assumptions. Academy of Management Journal 31(2): 428-438.

Zajonc RB. 1980. Feeling and thinking: Preferences need no inferences. American Psychologist 35(2): 151-175.

Zhang Y. 2008. Information asymmetry and the dismissal of newly appointed CEOs: an empirical investigation. Strategic Management Journal 29(8): 859-872.

Zhou L. 2014. A comparison of dynamic hazard models and static models for predicting the special treatment of stocks in China with comprehensive variables. Journal of the Operational Research Society 66(7): 1077-1090. 
TABLE 1

DESCRIPTIVE STATISTICS

\begin{tabular}{|c|c|c|c|c|c|c|c|c|c|c|c|c|c|c|c|c|c|c|c|c|}
\hline & Variable & Mean & S.D. & 1 & 2 & 3 & 4 & 5 & 6 & 7 & 8 & 9 & 10 & 11 & 12 & 13 & 14 & 15 & 16 & 17 \\
\hline 1 & Exec ship jumping & 0.28 & 0.45 & - & & & & & & & & & & & & & & & & \\
\hline 2 & Exec social capital & 2.72 & 0.55 & .46 & - & & & & & & & & & & & & & & & \\
\hline 3 & Peer social capital & 1.64 & 0.79 & .12 & -.09 & - & & & & & & & & & & & & & & \\
\hline 4 & Alliance network & 2.21 & 0.59 & .01 & -.24 & .25 & - & & & & & & & & & & & & & \\
\hline 5 & Executive age & 20.16 & 2.29 & -.42 & -.06 & -.39 & -.28 & - & & & & & & & & & & & & \\
\hline 6 & Exe share holding & 2.21 & 1.36 & -.10 & -.07 & .06 & .02 & .04 & - & & & & & & & & & & & \\
\hline 7 & Firm age & 0.22 & 0.41 & .03 & .07 & .07 & -.02 & -.03 & .05 & - & & & & & & & & & & \\
\hline 8 & Compensation & 10.43 & 2.15 & .06 & .03 & .01 & .31 & -.04 & -.20 & .04 & - & & & & & & & & & \\
\hline 9 & Asset scale & 4.21 & 0.59 & .02 & .04 & .16 & -.01 & -.05 & .00 & .03 & -.06 & - & & & & & & & & \\
\hline 10 & Education & 0.32 & 0.20 & .04 & .00 & -.01 & .04 & -.10 & -.05 & -.08 & -.03 & -.36 & - & & & & & & & \\
\hline 11 & Tenure & 0.01 & 0.10 & .05 & .01 & -.02 & .10 & -.03 & -.03 & -.05 & -.02 & .00 & -.02 & - & & & & & & \\
\hline 12 & Board size & 0.16 & 0.36 & .01 & -.02 & .06 & -.02 & -.06 & -.01 & .06 & .01 & .05 & .05 & -.04 & - & & & & & \\
\hline 13 & Gender & 0.03 & 0.18 & .08 & .05 & -.10 & -.02 & -.04 & .00 & -.06 & -.01 & -.01 & .06 & -.02 & -.08 & - & & & & \\
\hline 14 & Board chair & 2.18 & 1.30 & -.06 & -.21 & .13 & .15 & -.13 & .05 & -.07 & -.03 & -.08 & .24 & -.05 & -.04 & .07 & - & & & \\
\hline 15 & CEO & 1.96 & 1.23 & .00 & -.12 & .25 & .11 & -.10 & .05 & .04 & .05 & .04 & .07 & -.04 & .05 & .05 & .18 & - & & \\
\hline 16 & ROA & 9.80 & 3.38 & .15 & .14 & .28 & .03 & -.12 & -.06 & .10 & .06 & .00 & -.03 & .00 & -.04 & -.09 & -.06 & .03 & - & \\
\hline 17 & Other inside director & 0.04 & 0.08 & -.09 & -.07 & -.01 & .08 & -.01 & -.05 & .01 & -.01 & .03 & .09 & .01 & -.04 & .03 & .10 & .00 & -.08 & - \\
\hline 18 & SOE & 0.07 & 0.26 & -.07 & .01 & -.02 & -.08 & .12 & .01 & .11 & .07 & .05 & -.09 & -.03 & -.12 & -.05 & -.08 & .00 & -.09 & .02 \\
\hline
\end{tabular}

$\mathrm{N}=278$. Correlation coefficients with a magnitude greater than 0.10 are significant at the $p<0.05$ level (two-tailed test). 
TABLE 2

COX MODEL OF EXECUTIVE SHIP JUMPING

\begin{tabular}{|c|c|c|c|c|}
\hline & \multicolumn{2}{|c|}{ Model 1} & \multicolumn{2}{|c|}{ Model 2} \\
\hline Variable & $\begin{array}{c}\text { Haz. Ratio } \\
\text { (Robust Sd.) }\end{array}$ & $\begin{array}{c}\mathrm{z} \\
\text { (P-value) }\end{array}$ & $\begin{array}{c}\text { Haz. Ratio } \\
\text { (Robust Sd.) }\end{array}$ & $\begin{array}{c}\mathrm{z} \\
\text { (P-value) }\end{array}$ \\
\hline \multicolumn{5}{|l|}{ Executive-Level Controls } \\
\hline Executive age & $0.75(0.04)$ & $-5.23(0.00)$ & $0.50(0.02)$ & $-14.31(0.00)$ \\
\hline Education & $0.96(0.06)$ & $-0.67(0.50)$ & $0.99(0.05)$ & $-0.20(0.84)$ \\
\hline Gender & $1.03(0.17)$ & $0.15(0.88)$ & $0.81(0.11)$ & $-1.50(0.13)$ \\
\hline Tenure & $0.97(0.03)$ & $-1.00(0.32)$ & $1.05(0.02)$ & $2.54(0.01)$ \\
\hline Compensation & $0.89(0.10)$ & $-1.01(0.31)$ & $0.99(0.11)$ & $-0.09(0.93)$ \\
\hline Executive share holding & $2.11(0.92)$ & $1.72(0.09)$ & $0.78(0.31)$ & $-0.62(0.53)$ \\
\hline CEO & $1.37(0.41)$ & $1.07(0.29)$ & $1.71(0.60)$ & $1.52(0.13)$ \\
\hline Board chair & $0.98(0.20)$ & $-0.09(0.93)$ & $1.02(0.20)$ & $0.09(0.93)$ \\
\hline Other inside director & $1.33(0.29)$ & $1.33(0.19)$ & $1.25(0.27)$ & $1.05(0.29)$ \\
\hline \multicolumn{5}{|l|}{ Firm-Level Controls } \\
\hline Firm age & $0.95(0.08)$ & $-0.63(0.53)$ & $0.99(0.07)$ & $-0.12(0.90)$ \\
\hline Assets & $1.02(0.05)$ & $0.42(0.68)$ & $1.02(0.06)$ & $0.35(0.72)$ \\
\hline Board size & $1.03(0.02)$ & $1.10(0.27)$ & $1.06(0.03)$ & $2.27(0.02)$ \\
\hline ROA & $0.46(0.33)$ & $-1.09(0.27)$ & $0.29(0.10)$ & $-3.42(0.00)$ \\
\hline SOE & $0.98(0.38)$ & $-0.05(0.96)$ & $1.12(0.26)$ & $0.47(0.64)$ \\
\hline \multicolumn{5}{|l|}{ Key Independent Variables } \\
\hline Executive social capital & & & $3.43(0.68)$ & $6.17(0.00)$ \\
\hline Executive social capital squared & & & $0.16(0.05)$ & $-5.40(0.00)$ \\
\hline Peer social capital & & & $0.67(0.08)$ & $-3.38(0.00)$ \\
\hline Alliance network & & & $0.78(0.07)$ & $-2.69(0.01)$ \\
\hline Industry dummies & Included & & Included & \\
\hline Annual dummies & Included & & Included & \\
\hline Log pseudo-likelihood & -289.64 & & -245.01 & \\
\hline Wald Chi-square & 62.66 & & 683.10 & \\
\hline
\end{tabular}

a. The hazard rate of executive ship-jumping is the dependent variable. We report odds ratios and Z-scores based on robust standard errors. Odds ratios are interpreted as the proportional change in hazard rate from a one-unit increase in the independent variable. 1 indicates no change. Odds ratios lower than 1 indicate that increases in independent variables decrease the hazard rate, and those greater than 1 indicate that increases in independent variables increase the hazard rate. 
FIGURE 1

RELATIONSHIP BETWEEN EXECUTIVE SOCIAL CAPITAL AND EXECUTIVE SHIP JUMPING

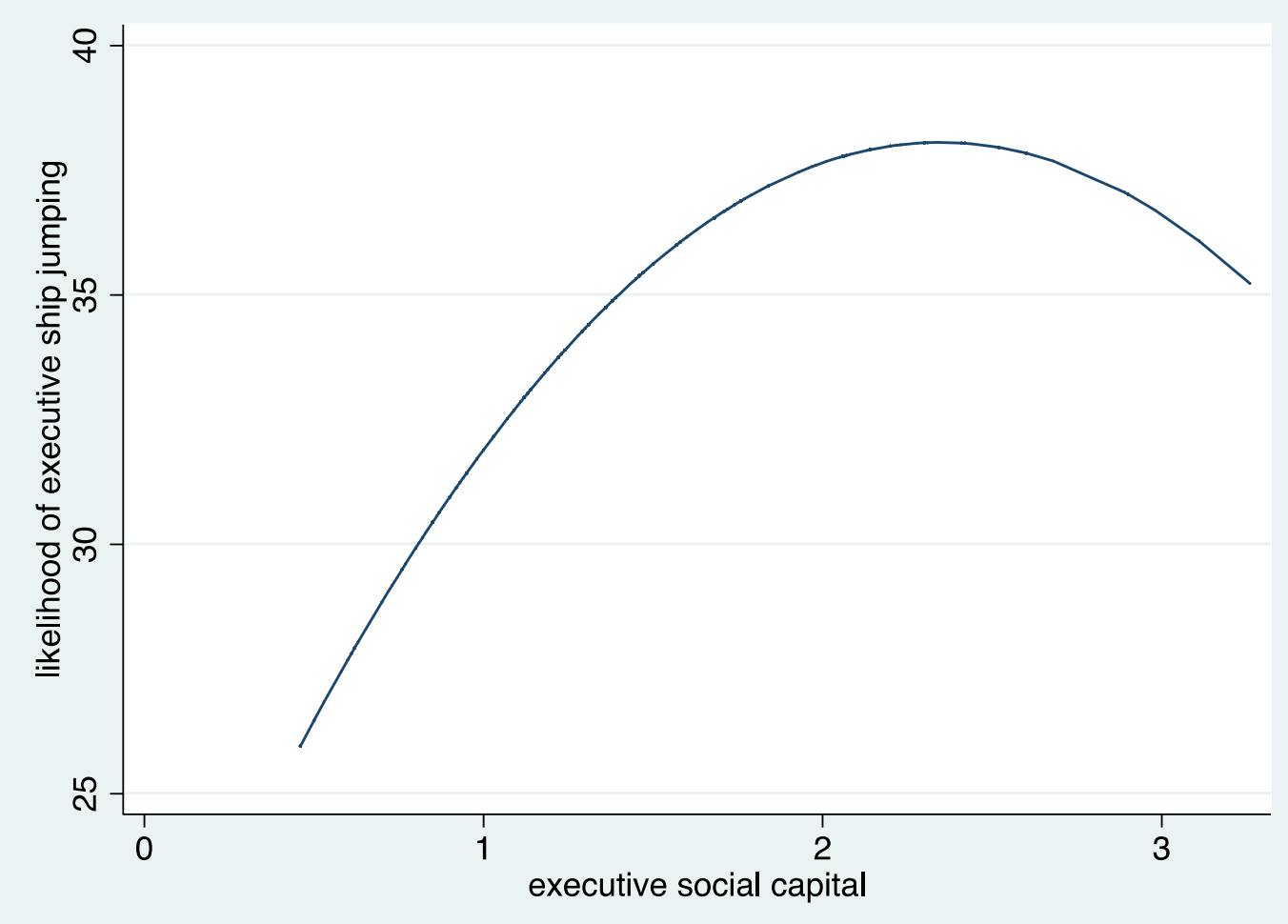




\section{APPENDIX 1 \\ COMPETING-RISK CONTRAST BETWEEN EXECUTIVE SHIP JUMPING AND EXECUTIVE DISMISSAL}

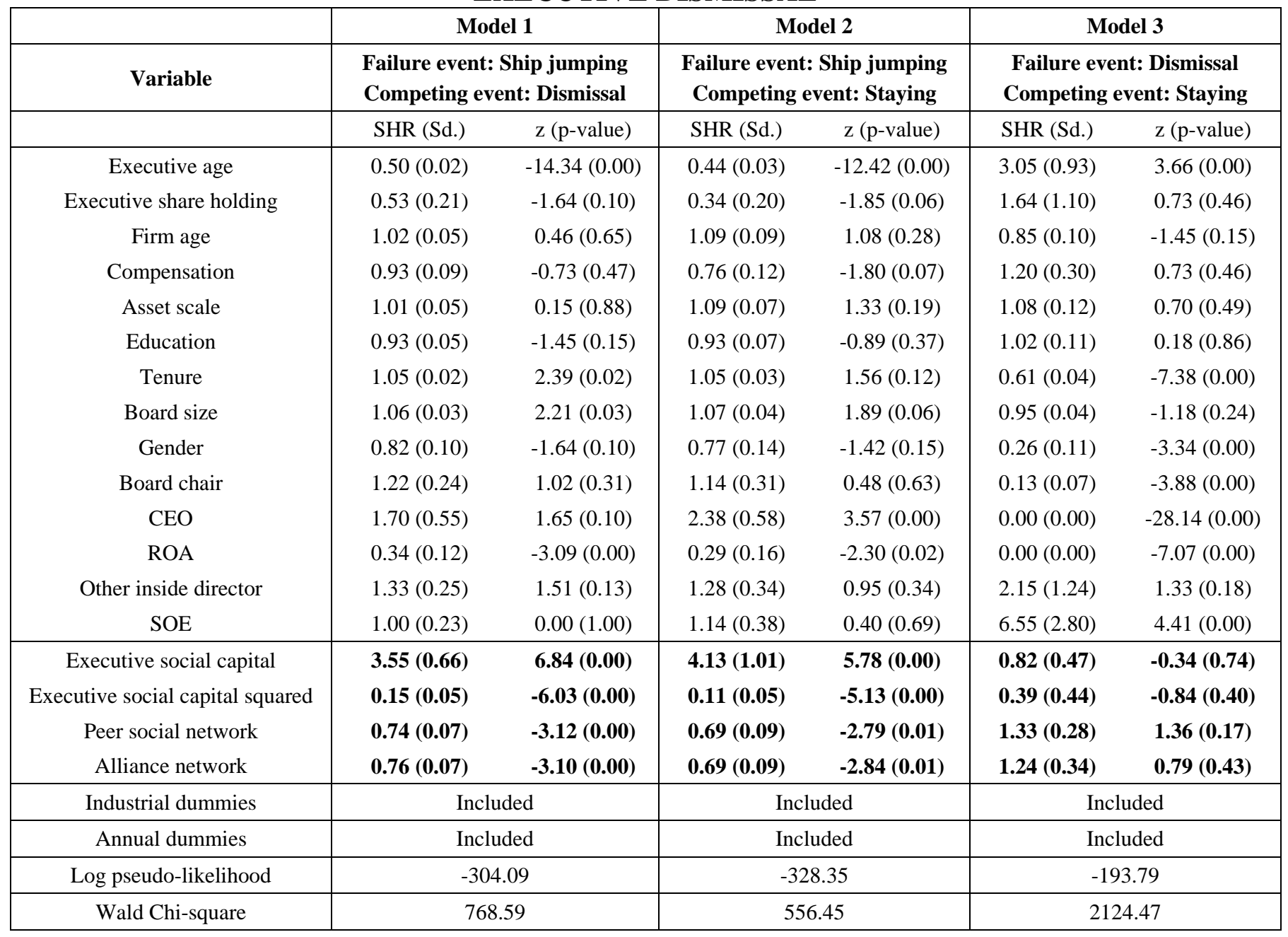

a SHR: Subdistribution Hazard Ratio

b We report SHR and Z-scores based on robust standard errors. SHRs lower than 1 indicate that increases in independent variables decrease the hazard rate, and those greater than 1 indicate that increases in independent variables increase the hazard rate. 1 indicates no change. 